\title{
PENAMBAHAN BUBUK DAN BUBUR KULIT BUAH NAGA (Hylocereus polyrhizus) DALAM PEMBUATAN PUDDING
}

\author{
(The Addition of Powder and Porridge of Dragon Fruit (Hylocereus \\ polyrhizus) in the production of Pudding)
}

\author{
Tri Marta Fadhilah ${ }^{a}$, Intan Ayu Sukmawati ${ }^{b}$, Ima Kristiana ${ }^{b}$, \\ Nurhani Azkia Kumalasarib ${ }^{\mathrm{b}}$, Nurul Liana ${ }^{\mathrm{b}}$ \\ ${ }^{a}$ Dosen Prodi S1 Gizi STIKes Mitra Keluarga, Bekasi, Indonesia \\ bMahasiswa Prodi S1 Gizi STIKes Mitra Keluarga, Bekasi, Indonesia \\ * Penulis koresponden: \\ Email: martafadhilah88@gmail.com
}

\begin{abstract}
Background: Pudding is one of the most popular type of dessert generally made from fresh fruit, but there is pudding that can be made from fruit skins i.e. dragon fruit skin. Objectives: to analyze the characteristics, acceptability, antioxidant activity and life span of dragon fruit skin pudding. Methods: It was an experimental design study that compared pudding with the addition of dragon fruit skin pulp $(225 \mathrm{ml}$ and $300 \mathrm{ml})$ and the powders (1gr and 2gr). This study used randomized block design and the results of statistical tests using ANOVA analysis and BNT test that showed a significant difference in taste, colour, aroma and texture. Result: the results of the hedonic test also showed that the highest public acceptance on F3 sample (225 $\mathrm{ml}$ of dragon fruit skin pulp) with score of color is 2.63, score of taste is 2.77, score of smell is 2.46 and score of texture is 2.46. The result of antioxidant activity test showed that the highest antioxidant activity was F2 sample (2gr dragon fruit powder) with 159.45 ppm. Conclusion: the dragon fruit skin pudding is acceptable to society and possesses antioxidant activity which can be affected by the producing of dragon fruit skin pudding.
\end{abstract}

Keywords: powder and porridge dragon fruit peel, dragon fruit feel pudding

\begin{abstract}
ABSTRAK
Latar Belakang: Puding merupakan salah satu jenis hidangan penutup yang banyak disukai oleh masyarakat. Pada umumnya puding dibuat dari buah segar akan tetapi ternyata beberapa kulit buah dapat digunakan juga, salah satunya yaitu kulit buah naga. Tujuan: untuk menganalisis karakteristik, daya terima, aktifitas antioksidan dan umur simpan puding kulit buah naga. Metode: desain penelitian yang digunakan yaitu penelitian experimental design yang membandingkan dua kelompok dengan penambahan bubur kulit buah naga ( $225 \mathrm{ml}, 300 \mathrm{ml}$ ) dan bubuk ( $1 \mathrm{gr}, 2 \mathrm{gr})$. Rancangan penelitian yang digunakan adalah rancangan acak kelompok (RAK). Hasil uji statistik menggunakan analisis ANOVA dan dilanjutkan dengan uji BNT didapatkan hasil adanya beda nyata pada indikator rasa, warna, aroma dan tekstur. Hasil: uji hedonik didapatkan daya terima masyarakat tertinggi pada sampel F3 (225ml bubur kulit buah naga) dengan skor warna 2,63 (suka), rasa 2,77 (suka), aroma 2,46 (suka) dan tesktur 2,46 (suka). Hasil uji aktivitas antioksidan didapatkan paling tinggi aktivitas antioksidannya yaitu sampel F2 (2gr bubuk buah naga) dengan aktivitas antioksidan 159,45 ppm. Kesimpulan: Puding kulit buah naga dapat diterima oleh masyarakat dan terdapat aktivitas antioksidan, oleh karena itu faktor pengolahan dapat mempengaruhi aktivitas antioksidan.
\end{abstract}

Kata kunci: bubuk dan bubur kulit buah naga, puding kulit buah naga 


\section{PENDAHULUAN}

\begin{tabular}{lcr}
\multicolumn{1}{c}{ Dalam era modern } & dengan \\
perkembangan & teknologi & dan ilmu \\
pengetahuan, & kehidupan & sehari-hari
\end{tabular} masyarakat tidak dapat terbebas dari senyawa radikal bebas seperti asap rokok, makanan yang digoreng, dibakar, paparan sinar matahari berlebih, asap kendaraan bermotor, obat-obat tertentu, racun dan polusi udara. Selain itu, lingkungan yang banyak mengandung senyawa radikal bebas dapat memicu terjadinya penurunan kualitas hidup masyarakat penyakit khususnya penyakit tidak menular (Arnanda,dkk. 2019).

Menurut World Health Organization (WHO) tahun 2017 dalam IHME, Penyakit tidak menular (PTM) menjadi penyebab utama kematian secara global. Lebih dari dua pertiga $(70 \%)$ dari populasi global akan meninggal akibat penyakit tidak menular seperti kanker, penyakit jantung, stroke dan diabetes. Data prevalensi penyakit tidak menular di Jawa Barat pada tahun 2013 tertinggi yaitu, penyakit hipertensi $9,67 \%$, asma $2,8 \%$, dan kanker $1,41 \%$, diabetes $1,3 \%$, jantung $1,6 \%$, stroke $11,4 \%$, dan ginjal $0,48 \%$ (Riskesdas, 2018). Sedangkan prevalensi penyakit tidak menular di Kota Bekasi pada tahun 2018 penyakit hipertensi $8,83 \%$, asma $3,03 \%$, dan diabetes mellitus $1,71 \%$ (Riskesdas, 2018).

Antioksidan merupakan senyawa yang mampu menangkal atau meredam dampak negatif oksidan dalam tubuh. Keseimbangan oksidan dan antioksidan sangat penting karena berkaitan dengan fungsinya sistem imunitas tubuh. Defisiensi antioksidan yang berupa vitamin $\mathrm{C}$, vitamin $\mathrm{E}$, Se, $\mathrm{Zn}$, dan glutation dalam derajat ringan hingga berat, sangat berpengaruh terhadap respons imun (Winarsi, 2007).

Tanaman buah naga adalah tanaman dari beberapa jenis kaktus atau famili cactaceae dan subfamili hylocereus. Dalam subfamili ini terdapat beberapa genus, sedangkan buah naga termasuk dalam genus Hylocereus. Genus ini terdiri dari 16 spesies, dua diantaranya memiliki buah yang komersial, yaitu Hylocereus Undatu (berdaging putih) dan Hylocereus costaricensis (daging merah) (Kristanto, 2008). Buah berbentuk bulat lonjong dengan ketebalan kulit buah 2-3 cm dan setiap buah terdapat sekitar 1.200-2.300 biji dengan berat rata-rata 400-500 gr. Kulit buah naga merah ditemukan positif mengandung senyawa alkaloid, steroid, saponin, dan tanin serta vitamin C (Noor,dkk. 2016). Kulit buah naga merah kaya akan sumber polyphenol dan antioksidan.

Aktivitas antioksidan kulit buah naga merah lebih besar daripada aktivitas daging buahnya. Kandungan antioksidan pada kulit buah naga dapat digunakan sebagai inhibitor organik. persentase kulit buah naga merah adalah 30\% hingga $35 \%$ dari berat buahnya. Hal ini sesuai dengan penelitian yang dilakukan oleh Nurliyana, dkk. (2010) yang menyatakan bahwa di dalam $1 \mathrm{mg} / \mathrm{ml}$ kulit buah naga merah mampu menghambat $83,48 \pm 1,02 \%$ radikal bebas, sedangkan pada daging buah naga hanya mampu menghambat radikal bebas sebesar 27,45 kurang lebih $5,03 \%$. Upaya dalam mencegah terjadinya radikal bebas dilakukan dengan menerapkan makanan atau minuman yang dapat meningkatkan sistem imunitas tubuh, salah satunya yaitu puding dengan ekstrak kulit buah naga yang terdapat senyawa antioksidan.

Puding merupakan salah satu jenis hidangan penutup yang pada umumnya disajikan pada akhir suatu jamuan makan atau sebagai penutup (dessert) dan puding yang umumnya dibuat dari bahan-bahan yang direbus, dikukus, atau dipanggang (Arini, 2015). Oleh karena itu peneliti tertarik membuat pudding yang cara pembuatannya mudah dan banyak disukai oleh masyarakat dengan menambahan ekstrak kulit buah naga.

\section{BAHAN DAN METODE Bahan Pembuatan Puding \\ Bahan yang digunakan dalam pembuatan puding penelitian ini adalah bubur kulit buah naga, bubuk kulit buah}


Tabel 1. Formula Bahan pudding kulit buah naga

\begin{tabular}{|c|c|c|c|c|}
\hline \multirow[t]{2}{*}{ Bahan } & \multicolumn{2}{|c|}{$\begin{array}{c}\text { Formula Bubur Kulit Buah } \\
\text { Naga }\end{array}$} & \multicolumn{2}{|c|}{ Formula Bubuk Kulit Buah Naga } \\
\hline & F1R $(30 \%)$ & F2R (40\%) & F1K (6\%) & F2K (13\%) \\
\hline Bubur Kulit Buah Naga & $225 \mathrm{ml}$ & $300 \mathrm{ml}$ & 0 & 0 \\
\hline Bubuk Kulit Buah Naga & 0 & 0 & $1 \mathrm{gr}$ & $2 \mathrm{gr}$ \\
\hline Bubuk Agar & $15 \mathrm{gr}$ & $15 \mathrm{~g}$ & $14 \mathrm{~g}$ & $13 \mathrm{gr}$ \\
\hline Vanili & $2 \mathrm{gr}$ & $2 \mathrm{gr}$ & $2 \mathrm{gr}$ & $2 \mathrm{gr}$ \\
\hline Gula stevia & $13 \mathrm{gr}$ & $13 \mathrm{~g}$ & $13 \mathrm{~g}$ & $13 \mathrm{~g}$ \\
\hline Susu & $250 \mathrm{ml}$ & $250 \mathrm{ml}$ & $500 \mathrm{ml}$ & $500 \mathrm{ml}$ \\
\hline Air & $275 \mathrm{ml}$ & $200 \mathrm{ml}$ & $250 \mathrm{ml}$ & $250 \mathrm{ml}$ \\
\hline
\end{tabular}

Sumber dari modifikasi dari Jurnal (Renny, dkk 2017) dan (Sulistianingsih, dkk. 2017).

naga, bubuk agar, vanili, gula stevia, susu, air dengan formula pada Tabel 1 .

Alat yang digunakan dalam pembuatan puding kulit buah naga yaitu panci, sendok, centong sayur, cetakan puding, timbangan, lemari es, kompor. Proses pembuatan puding dengan cara pembuatan ekstrak kulit buah naga yang berupa bubuk dan bubur kulit buah naga. Bubur kulit buah naga dibuat dengan cara kulit buah naga yang sudah dibuang bonggol dan sisik atau jumbai berwarna hijau serta dicuci bersih lalu dihaluskan menggunakan blender dengan ditambahkan air dan untuk bubuk buah naga yang digunakan adalah bubuk kulit buah naga instan. Setelah itu bubuk dan bubur kulit buah naga tersebut ditambahkan pada pembuatan pudding. Penambahan bubur kulit buah naga $(30 \%, 50 \%)$ dan penambahan bubuk kulit buah naga $(6 \%, 13 \%)$.

\section{Bahan Uji Antioksidan}

Bahan yang digunakan dalam pengujian aktivitas antioksidan pada pudding kulit buah naga yaitu sampel produk pudding kulit buah naga, 1,1-diphenyl-2-hydrazil, etanol, metanol Pro Analysis, dan aquades.

Alat yang digunakan untuk melakukan pengujian aktivitas antioksidan pada pudding kulit buah naga adalah Labu takar, mikropipet, inkubator, neraca digital, beaker glass, timbangan analitik, spektrofotometer UV-VIS, tabung reaksi dan erlemmeyer.

\section{Metode Uji Antioksidan}

Proses pengujian aktivitas antioksidan yaitu pengujian antioksidan sampel, pembuatan larutan stock DPPH, penentuan nilai IC 50 dan perhitungan persentase aktivitas antioksidan dengan rumus. Menurut Tristantini 2016, cara pengujian antioksidan yaitu:

1. Pengujian antioksidan sampel

Siapkan sempel dan siapkan larutan induk dengan melarutkan $10 \mathrm{mg}$ sampel pada $100 \mathrm{ml}$ petanol Pa. Selanjutnya melakukan pengenceran menggunakan pelarut metanol PA dengan membuat variasi konsentrasi 5 ppm, 6 ppm, 7 ppm, 8 ppm dan 9 ppm.

2. Pembuatan larutan stock DPPH 50 ppm

Siapkan larutan DPPH dengan melarutkan $5 \mathrm{mg}$ padatan DPPH kedalam $100 \mathrm{ml}$ metanol PA. Selanjutnya siapkan larutan perbandingan, yaitu larutan kontrol yang berisi $2 \mathrm{ml}$ metanol PA dan $1 \mathrm{ml}$ larutan DPPH 50 ppm.

3. Penentuan nilai IC 50

Siapakan masing-masing $2 \mathrm{ml}$ larutan sampel dan $2 \mathrm{ml}$ larutan $\mathrm{DPPH}$, lalu diinkubasi selama 30 menit pada suhu $27^{\circ} \mathrm{C}$ hingga terjadi perubahan warna dari aktivitas DPPH yaitru dari semula warna ungu tua menjadi warna kuning terang. Sampel yang telah diinkubasi diuji nilai absorbansinya menggunakan spektrofotometer Uv-Vis pada panjang gelombang $517 \mathrm{~nm}$. 
Tabel 2. Kriteria Skala Uji Organoleptik

\begin{tabular}{ccccc}
\hline Skor & Warna & Aroma & Tekstur & Rasa \\
\hline 1 & Tidak Pink & Tidak Sedap & Tidak Kesar & Tidak Manis \\
2 & Cukup Pink & Cukup Sedap & Cukup lembut & Cukup manis \\
3 & Pink & Sedap & Lembut & Manis \\
4 & Sangat Pink & Sangat Sedap & Sangat Lembut & Sangat Manis \\
\hline
\end{tabular}

Tabel 3. Kriteria Skala Uji Hedonik/Kesuakaan

\begin{tabular}{ccccc}
\hline Skor & Warna & Aroma & Tekstur & Rasa \\
\hline 5 & Sangat suka & Sangat suka & Sangat suka & Sangat suka \\
4 & Cukup suka & Cukup suka & Cukup suka & Cukup suka \\
3 & Suka & Suka & Suka & Suka \\
2 & Tidak Suka & Tidak Suka & Tidak Suka & Tidak Suka \\
1 & Sangat Tidak Suka & Sangat Tidak Suka & Sangat Tidak Suka & Sangat Tidak Suka \\
\hline
\end{tabular}

Tabel 4. Interval kelas rerata dan kriteria uji organoleptik

\begin{tabular}{|c|c|c|c|c|}
\hline \multirow{2}{*}{ Aspek } & \multicolumn{4}{|c|}{ Rerata skor } \\
\hline & $1 \leq x<1,75$ & $1,75 \leq x<2,5$ & $2,5 \leq x<3,25$ & $3,25 \leq x<4$ \\
\hline Aroma & $\begin{array}{l}\text { Tidak beraroma khas } \\
\text { buah naga }\end{array}$ & $\begin{array}{l}\text { Kurang beraroma } \\
\text { khas buah naga }\end{array}$ & $\begin{array}{l}\text { Beraroma khas } \\
\text { buah naga }\end{array}$ & $\begin{array}{l}\text { Sangat beraroma } \\
\text { khas buah naga }\end{array}$ \\
\hline Rasa & Tidak Manis & Kurang Manis & Manis & Sangat Manis \\
\hline Warna & Tidak pink & Cukup pink & Pink & Sangat pink \\
\hline Tekstur & Keras & Kurang lembut & Lembut & Sangat Lembut \\
\hline
\end{tabular}

Tabel 5. Presentase Uji Hedonik

\begin{tabular}{cc}
\hline Persentase $(\%)$ & Kriteria \\
\hline $84-100$ & Sangat suka \\
$68-83,99$ & Suka \\
$52-67,99$ & Cukup suka \\
$36-51,99$ & Kurang suka \\
$20-35,99$ & Tidak suka \\
\hline
\end{tabular}

Data hasil pengukuran absorbansi dianalisis persentase aktivitas antioksidannya menggunakan persamaan berikut:

$$
\% \text { Antioksidan }=\frac{A_{c}-A}{A_{c}} \times 100 \%
$$

Keterangan:

$A_{c}=$ Nilai absorbansi Kontrol

$A=$ Nilai Absorbansi Sampel

\section{Bahan Uji Organoleptik dan Hedonik}

Bahan yang digunakan untuk menguji organoleptik dan hedonik adalah kuesioner terkait uji inderawi manusia yang diberikan kepada 35 panelis tidak terlatih. Panelis diminta untuk memberikan penilaian terkait produk yang diberikan yaitu puding bubur buah kulit buah naga dan puding bubuk kulit buah naga. Di dalam kuesioner tersebut berisikan penilaian terhadap warna, tekstur, aroma dan rasa dari produk yang akan dinilai serta penilaian terkait kesukaan terhadap produk. Kriteria penilaian dapat dilihat pada Tabel 2 dan Tabel 3 (Maulina, 2015).

\section{Metode Uji Organoleptik dan Hedonik}

Metode perhitungan uji organoleptik pada penelitian ini dengan mengubah data kualitatif menjadi data kuantitatif. Kualitas yang akan dianalisa adalah aroma, rasa, warna. Berdasarkan hasil perhitungan diperoleh tabel interval skor dan kriteria puding hasil eksperimen. Tabel interval skor 
dan kriteria puding hasil eksperimen dapat dilihat pada Tabel 4.

Metode perhitungan uji hedonik pada penelitian ini menggunakan analisis deskriptif presentasi dengan perhitungan didapatkan hasil interval presentase dengan kriteria uji kesukaan dari masing masing aspek yaitu (warna, aroma, tekstur, dan rasa) pada Tabel 5.

\section{Bahan Uji Umur Simpan}

Penentuan umur simpan suatu produk didasarkan pada pendeteksian perubahan mikroba yang diiringi dengan perubahan fisik, kimia dan sensori bahan pangan seiring lamanya waktu penyimpanan (Asiah, dkk. 2018). Bahan yang digunakan dalam pengujian umur simpan adalah produk pudding kulit buah naga, almari pendingin atau kulkas. Alat yang digunakan untuk pengujian umur simpan pudding adalah cup plastik untuk penyimpanan 4 sampel puding kulit buah naga.

\section{Metode Uji Umur Simpan}

Pada uji umur simpan, Metode direct method paling banyak diterapkan dengan cara meletakkan produk pada sebuah ruang penyimpanan dengan kondisi tertentu selama waktu tertentu (lebih dari waktu perkiraan shelf life). Produk kemudian dicek secara berkala untuk melihat perubahan yang mungkin terjadi (baik secara quality maupun safety) (Asiah, dkk. 2018).

\section{Analisis Data}

Data yang diperoleh dianalisis menggunakan uji ANOVA satu arah dengan sempel yang berbeda yaitu 4 sampel. Uji beda digunakan untuk mengetahui perbedaan antara pudding kulit buah naga yang telah diberi tambahan kulit buah naga berupa bubuk dan bubur dalam segi sensori.

\section{HASIL DAN PEMBAHASAN Uji Organoleptik}

Kualitas organoleptik produk puding kulit buah naga dapat diukur dengan uji inderawi atau sensori. Uji inderawi yang dinilai dari aspek warna, aroma, rasa dan tekstur puding kulit buah naga.

Berdasarkan Tabel 6 menunjukan bahwa dari masing-masing hasil uji organoleptik pada penilian aspek warna, aroma, rasa dan tekstur didapatkan produk puding dengan penambahan bubuk kulit buah naga yang paling bagus hasilnya yaitu produk F2 dengan penambahan $13 \%$ bubuk kulit buah naga dengan hasil warna cukup pink, beraroma khas kulit buah naga, rasa manis dan tekstur lembut. Sedangkan puding dengan penambahan bubur kulit buah naga didapatkan hasil yang paling bagus pada produk F2B dengan penambahan 40\% bubur kulit buah naga dengan hasil warna pink, beraroma khas kulit buah naga, rasa manis dan tekstur lembut.

\section{Analisis Kualiatas Organoleptik}

Perbedaan kualitas organoleptik dilakukan menggunakan uji statistik ANOVA. Tujuan analisis ANOVA adalah untuk menentukan apakah terdapat perbedaan nyata dari 4 sampel. Pada hasil uji organoleptik didapatkan data memiliki analisis varian yang berbeda-beda.

\section{Kualitas Aroma}

Kualitas aroma yang diukur dengan indikator kriteria dan skornya yaitu: Tidak Pink (1), Cukup Pink (2), Pink (3), Sangat Pink (4).

Tabel 7. Hasil Analisis perbedaan kualitas pudding indikator aroma

\begin{tabular}{|c|c|c|c|c|c|c|}
\hline SK & DB & JK & KT & $\begin{array}{c}\mathbf{F} \\
\text { hitung }\end{array}$ & $\begin{array}{c}F \\
\text { tabel }\end{array}$ & Keterangan \\
\hline Sampel & 3 & 3.02 & 1.00 & \multirow{4}{*}{3.74} & \multirow{4}{*}{2.70} & \multirow{4}{*}{$\begin{array}{l}\text { Berbeda } \\
\text { nyata }\end{array}$} \\
\hline Panelis & 34 & 29.67 & 0.87 & & & \\
\hline Galat & 102 & 27.47 & 0.26 & & & \\
\hline Total & 139 & 60.17 & & & & \\
\hline
\end{tabular}

Pada hasil analisis perbedaan dapat dilihat penilaian aroma puding kulit buah naga oleh panelis sebesar (3.74) dengan nilai $\alpha=0,05$ yaitu (2.70) yang menunjukkan bahwa penambahan bubuk dan bubur kulit buah naga memberikan pengaruh yang nyata terhadap aroma puding kulit buah 
naga. Hal ini dikarenakan kulit buah naga merah memiliki citarasa langu sehingga dengan semakin banyak penambahan kulit buah naga merah dapat mengurangi aroma susu. Sejalan dengan Wahyuni (2011) menyatakan bahwa semakin banyak pemberian kulit buah naga merah pada produk maka akan tercium bau langu pada produk yang dibuat. Selain itu menurut Cahyadi dalam Ayu (2013), menyebutkan bahwa aroma merupakan salah satu parameter yang menentukan rasa enak pada suatu makanan. Hal ini dapat menyebabkan semaikin banyak penggunaan kulit buha naga maka aroma kulit buah naga pada puding akan lebih terasa. Menurut Siwi (2018) pada penelitian penambahan kulit buah naga pada permen jelly jagung, pemberian 20-35 gr kulit buah naga akan beraroma langu, aroma langu didapatkan dari ekstrak kulit buah naga merah karena ekstrak kulit buah naga merah mengandung senyawa tanin yang menyebabkan aroma langu.

\section{Kualitas Rasa}

Kualitas rasa yang diukur dengan indikator kriteria dan skornya yaitu Tidak manis (1), Kurang manis (2), Manis (3), Sangat manis (4).

Tabel 8. Hasil analisis perbedaan kualitas pudding indikator rasa

\begin{tabular}{|c|c|c|c|c|c|c|}
\hline SK & DB & JK & KT & $\begin{array}{c}\mathbf{F} \\
\text { hitung }\end{array}$ & $\begin{array}{c}\mathbf{F} \\
\text { tabel }\end{array}$ & Keterangan \\
\hline Sampel & 3 & 2.93 & 0.97 & \multirow{4}{*}{3.86} & \multirow{4}{*}{2.70} & \multirow{4}{*}{$\begin{array}{c}\text { Berbeda } \\
\text { nyata }\end{array}$} \\
\hline Panelis & 34 & 47.67 & 1.40 & & & \\
\hline Galat & 102 & 25.81 & 0.25 & & & \\
\hline Total & 139 & 76.42 & & & & \\
\hline
\end{tabular}

Pada hasil analisis perbedaan dapat dilihat penilaian rasa pudding kulit buah naga oleh panelis sebesar (3.86) dengan nilai $\alpha=$ 0,05 yaitu (2.70) yang menunjukkan bahwa penambahan bubuk dan bubur kulit buah naga memberikan pengaruh yang nyata terhadap aroma puding kulit buah naga. Rasa merupakan kriteria penting dalam menilai suatu produk pangan. Winarno dalam Intan (2013) mengemukakan bahwa rasa dipengaruhi oleh interaksi dengan komponen rasa lain. Pada produk puding kulit buah naga mendapati hasil dari semua sampel menyatakan manis, karena penggunaan gula stevia sebagai pemanis yang tidak memiliki kalori, dan pemberian kulit buah naga tidak berdampak rasa produk. Sejalan dengan penelitian Raini (2011) Daun stevia mengandung pemanis alami non kalori dan mampu menghasilkan rasa manis $70-400$ kali dari manisnya gula tebu.

\section{Kualitas Warna}

Kualitas rasa yang diukur dengan indikator kriteria dan skornya yaitu: Tidak Pink (1), Cukup Pink (2), Pink (3), Sangat Pink (4).

Tabel 9. Hasil analisis perbedaan kualitas puding indikator warna

\begin{tabular}{|c|c|c|c|c|c|c|}
\hline SK & DB & JK & KT & $\begin{array}{c}\mathbf{F} \\
\text { hitung }\end{array}$ & $\begin{array}{c}F \\
\text { tabel }\end{array}$ & Keterangan \\
\hline Sampel & 3 & 18.70 & 6.23 & \multirow{4}{*}{8.27} & \multirow{4}{*}{2.70} & \multirow{4}{*}{$\begin{array}{l}\text { Berbeda } \\
\text { nyata }\end{array}$} \\
\hline Panelis & 34 & 13.64 & 0.40 & & & \\
\hline Galat & 102 & 77.04 & 0.75 & & & \\
\hline Total & 139 & 109.39 & & & & \\
\hline
\end{tabular}

Pada hasil analisis perbedaan dapat dilihat penilaian warna puding kulit buah naga oleh panelis sebesar (8.27) dengan nilai $\alpha=0,05$ yaitu (2.70) yang menunjukkan bahwa penambahan bubuk dan bubur kulit buah naga memberikan pengaruh yang nyata terhadap aroma puding kulit buah naga. Hal tersebut disebabkan karena penambahan ekstrak Kulit Buah Naga yang semakin banyak maka akan mempengaruhi warna pada puding. Sejalan dengan Sulistianingsih dkk (2017) Semakin banyak penambahan ekstak kulit buah naga merah maka semakin merah warna permen jelly yang dihasilkan. Ekstrak kulit buah naga merah pada pembuatan permen jelly dapat membantu memperbaiki tingkat kesukaan terhapat warna permen jelly yang dihasilkan. Selain itu juga warna pada Puding dipengaruhi oleh beberapa faktor ekstrak Kulit Buah Naga merah mengandung pigmen betasianin. Menurut hasil dari penelitian Arini (2015), menunjukkan bahwa semakin banyak penambahan bubuk kulit 
buah maka warna yang dihasilkan cerah atau lebih pekat.

\section{Kulitas Tesktur}

Kualitas tesktur yang diukur dengan indikator kriteria dan skornya yaitu: Keras (1), Kurang lembut (2), Lembut (3), Sangat lembut (4).

Tabel 10. Hasil analisis perbedaan kualitas pudding indikator warna

\begin{tabular}{lcccccc}
\multicolumn{1}{c}{ SK } & DB & JK & KT & $\begin{array}{c}\mathbf{F} \\
\text { hitung }\end{array}$ & $\begin{array}{c}\mathbf{F} \\
\text { tabel }\end{array}$ & Keterangan \\
\hline Sampel & 3 & 3.77 & 1.25 & & & \\
Panelis & 34 & 28.54 & 0.83 & 3.44 & 2.70 & $\begin{array}{c}\text { Berbeda } \\
\text { nyata }\end{array}$ \\
Galat & 102 & 37.22 & 0.36 & & & \\
\cline { 1 - 3 } Total & 139 & 69.54 & & & & \\
\hline
\end{tabular}

Pada hasil analisis perbedaan dapat dilihat penilaian tekstur pudding kulit buah naga oleh panelis sebesar (3.44) dengan nilai $\alpha=0,05$ yaitu (2.70) yang menunjukkan bahwa penambahan bubuk dan bubur kulit buah naga memberikan pengaruh yang nyata terhadap tekstur puding kulit buah naga. Hal ini disebabkan karena kulit buah naga mengandung pektin yang juga dapat menambah kekenyalan dari suatu produk (Wahyuni, 2011). Daya terima tekstur juga merupakan salah satu sifat fisik bahan pangan yang turut menentukan cita rasa makanan karena sensitivitas indera (Arysanti dkk, 2019). Tekstur makanan juga merupakan komponen yang turut menentukan cita rasa makanan karena sensitifitas indera cita rasa dipengaruhi oleh konsistensi makanan.

\section{Uji Hedonik}

Analisis kesukaan masyarakat terhadap puding kulit buah naga menggunakan panelis sbanyak 35 orang dengan aspek yang dinilai adalah aspek rasa, warna, aroma, dan tekstur. Hasil uji kesukaan dapat dilihat pada tabel 11.

Berdasarkan Tabel 11, kriteria menyatakan interval presentase kesukaan masyarakat terhadap puding kulit buah naga berbeda-beda. hasil ini memperlihatkan bahwa tingkat kesukan masyarakat terhadap puding kulit buah naga dengan kode sampel (F1, F2, F3, F4). Perhitungan dari tabel tingkat kesukaan masyarakat terhadap puding kulit buah naga dari aspek rasa, warna, aroma, dan teksturnya didapatkan puding kulit buah naga yang sangat disukai oleh masyarakat dari segi aspek rasa, warna dan tekstur adalah puding kulit buah naga yang terbuat dari bubur kulit $225 \mathrm{ml}$ dengan persentase sebanyak $51.6 \%$. Hasil menunjukkan dengan penggunaan bubur kulit buah naga lebih dapat memberikan warna pink dibandingkan dengan menggunakan bubuk kulit buah naga yang tidak berwarna pink. Sehingga, semakin banyak penambahan bubur kulit buah naga merah maka semakin merah warna puding yang dihasilkan. Hal tersebut dikarenakan pada bubur kulit buah naga terdapat pigmen antosianin. Antosianin merupakan pigmen alami yang menyebabkan warna merah, jingga, ungu dan biru (Saneto, 2005) dengan penelitian yang dilakukan oleh paling disukai adalah penambahan buah naga $225 \mathrm{ml}$ bubur kulit buah naga. Selain itu dari segi rasa tertutupi dengan rasa stevia yang digunakan pada kedua puding tersebut. Menurut Tezar dkk, (2008) penambahan stevia yang tinggi maka rasa manis pun akan menjadi tinggi sehingga produk lebih disukai oleh masyarakat.

\section{Uji Aktivitas Antioksidan}

Uji kandungan gizi yang dilakukan adalah uji aktifitas antioksidan dengan 2 kali pengulangan pada Tabel 12.

Berdasarkan hasil analisis aktivitas antioksidan menyatakan bahwa formula yang paling tinggi aktifitas antioksidannya adalah F2 (2 gr bubuk kulit buah naga) dan F3 (225 ml bubur kulit buah naga) yaitu 159.45 dan 312.39 ppm. Berdasarkan nilai ppm pada hasil didapat semakin rendah nilai ppm nya maka aktifitas antioksidannya semakin tinggi.

Antioksidan adalah senyawa yang dapat menghambat atau menangkal proses oksidasi lipid. Radikal bebas merupakan pemicu sebagian besar penyakit tubuh dan merupakan bahan yang sangat berbahaya. 
Tabel 11. Hasil Uji Hedonik Puding Kulit Buah Naga

\begin{tabular}{lcccccc}
\hline \multirow{2}{*}{ Sampel } & \multicolumn{4}{c}{ Rata - Rata Aspek } & \multirow{2}{*}{ Presentase } & Kriteria \\
\cline { 2 - 5 } & R & W & A & T & Total & \\
\hline $\begin{array}{l}\text { Formula 1 (1 gr bubuk } \\
\text { kulit buah naga) }\end{array}$ & 2.46 & 2.46 & 2.54 & 2.43 & 49.45 & Suka \\
$\begin{array}{l}\text { Formula 2 (2 gr bubuk } \\
\text { kulit buah naga }\end{array}$ & 2.34 & 2.57 & 2.60 & 2.17 & 48.4 & Cukup suka \\
$\begin{array}{l}\text { Formula 1B (225 ml } \\
\text { bubur kulit buah naga) }\end{array}$ & 2.77 & 2.63 & 2.46 & 2.46 & 51.6 & Suka \\
$\begin{array}{l}\text { Formula 2B (300 ml } \\
\text { bubur kulit buah naga) }\end{array}$ & 1.94 & 2.23 & 2.29 & 2.42 & 44.75 & Cukup suka \\
\hline
\end{tabular}

Tabel 12. Hasil Uji Aktivitas Antioksidan

\begin{tabular}{|c|c|c|}
\hline Formula & $\begin{array}{c}\text { Aktivitas } \\
\text { Antioksidan }\end{array}$ & Interpretasi \\
\hline $\begin{array}{l}\text { Formula } 1 \text { ( } 1 \mathrm{gr} \\
\text { bubuk kulit buah } \\
\text { naga) }\end{array}$ & $\begin{array}{c}240,40 \\
\mathrm{ppm}\end{array}$ & $\begin{array}{l}\text { Sangat } \\
\text { lemah }\end{array}$ \\
\hline $\begin{array}{l}\text { Formula } 2 \text { ( } 2 \text { gr } \\
\text { bubuk kulit buah } \\
\text { naga }\end{array}$ & $\begin{array}{c}159.49 \\
\mathrm{ppm}\end{array}$ & Lemah \\
\hline $\begin{array}{l}\text { Formula 1B ( } 225 \\
\text { ml bubur kulit } \\
\text { buah naga) }\end{array}$ & $\begin{array}{c}312.39 \\
\mathrm{ppm}\end{array}$ & $\begin{array}{l}\text { Sangat } \\
\text { lemah }\end{array}$ \\
\hline $\begin{array}{l}\text { Formula } 2 \mathrm{~B} \text { ( } 300 \\
\text { ml bubur kulit } \\
\text { buah naga) }\end{array}$ & $\begin{array}{c}557.90 \\
\text { ppm }\end{array}$ & $\begin{array}{l}\text { Sangat } \\
\text { lemah }\end{array}$ \\
\hline
\end{tabular}

Oksidan dan antioksidan berkaitan dengan fungsinya sistem imunitas tubuh. Antioksidan juga mampu menghambat reaksi oksidasi. Penyebab utama kerusakan oksidatif di dalam tubuh adalah senyawa oksidan, kerusakan ini terjadi akibat kurangnya oksidan di dalam tubuh (Winahyu, dkk, 2019).

Pada kulit buah naga mengandung vitamin $C$, vitamin $E$, vitamin $A$, alkaloid, terpenoid, flavonoid, tiamin, niasin, piridoksin, kobalamin, fenolik, karoten, dan fitoalbumin yang diduga juga memiliki manfaat sebagai antioksidan (Mahargyani, 2018). Parameter yang digunakan dalam pengujian aktivitas antioksidan dengan penangkapan radikal DPPH ini adalah nilai konsentrasi hambatan atau Inhibitory Concentration (IC50) atau efficient concentration (EC50). Semakin kecil nilai IC50, maka semakin aktif sampel tersebut sebagai antioksidan. Berdasarkan persamaan regresi linear yang diperoleh, nilai IC50 atau konsentrasi yang dibutuhkan untuk menangkap radikal DPPH (Budilaksono, dkk, 2014).

Aktivitas antioksidan dapat dibagi menjadi kategori sangat kuat, kuat, sedang, lemah, dan sangat lemah. Antioksidan dikatakan sangat kuat apabila memiliki nilai IC50 kurang dari 50 ppm, antioksidan kuat memiliki nilai IC50 berada pada kisaran 50 ppm hingga 100 ppm, antioksidan sedang memiliki nilai IC50berkisar antara 100 ppm hingga 150 ppm, antioksidan lemah memiliki kisaran 150 ppm hingga 200 ppm dan nilai IC50 lebih dari 200 ppm merupakan antioksidan berkategori sangat lemah (Purwanto, dkk, 2017). Pada hasil penelitian yang dilakukan mendapati hasil aktivitas antioksidan puding kulit buah naga $\mathrm{F} 1$ (bubuk kulit buah naga 1 gr) 240.40 ppm, F2(bubuk kulit buah naga 2 gr) 159.45 ppm, F1B (bubur kulit buah naga 250ml) 312.39 ppm dan F2B (bubur kulit buah naga $300 \mathrm{ml}$ ) 557.90 ppm. Pada hasil uji aktivitas antioksidan di atas menunjukan bahwa aktivitas antioksidan pada puding kulit buah naga lemah sampai sangat lemah untuk melawan radikal bebas.

Pada Hasil puding kulit buah naga lemah didapatkan nilai paling rendah sebesar 159.45 ppm pada F2 (Bubuk kulit buah naga 2 gr) dan nilai sangat lemah sebesar 557.90 ppm pada F2 (Bubur kulit buah naga $300 \mathrm{ml}$ ) penyebab lemahnya disebabkan berbagai faktor, seperti proses pemasakan puding sampai mendidih, sejalan dengan hasil penelitian Aryantini (2021) penurunan aktivitas antioksidan disebabkan proses pemanasan semakin lama pemanasan menunjukkan penurunan yang signifikan. Hal ini diduga karena pemanasan akan 
mengakibatkan kerusakan pada jaringan buah. Pada kulit buah naga terdapat antosianin merupakan senyawa antioksidan yang tidak stabil apabila terkena panas. Pigmen antosinanin (merah, ungu dan biru) merupakan molekul yang tidak stabil jika terjadi perubahan pada suhu, $\mathrm{pH}$, oksigen, cahaya, dan gula (Aryantini, 2021). Selain itu disebabkan karena proses lama penyimpanan ektrak kulit buah naga seperti bubuk, bubuk yang di gunakan bubuk yang dibeli online dan sudah dibuat 2 bulan sebelum pembelian, sejalan dengan penelitian (Utami, dkk. 2020) proses penyimpanan ektrak dapat mempengaruhi aktivitas antioksidan, semakin lama proses penyimpanan akan mengalami pengurangan aktivitas antioksidan.

Penelitian (Suparmajid, dkk. 2016) pada lama penyimpanan kunyit, semakin lama masa penyimpanan kunyit menyebabkan penurunan antioksidan, pada penyimpanan 8 hari, 13 hari dan 18 hari. Hal ini berarti kemampuan antioksidan dalam meredam radikal bebas semakin berkurang yang menyatakan bahwa daya hambat antioksidan juga berkurang. Selain itu pengaruh suhu selama penyimpanan berpengaruh terhadap aktivitas antioksidan karena setelah dipanen rimpang kunyit ditumpuk sehingga dapat menyebabkan perubahan keasaman, dan yang paling penting adalah pengaruh dari kerusakan mekanik dan memar, karena akan sangat mudah mengalami pembusukan dan jika dimasukkan dalam tumpukan rimpang kunyit lainnya maka proses pembusukan akan semakin cepat terjadi dan pada akhirnya akan mengurangi zat gizi yang terkandung. Sejalan dengan penelitian (Suparmajid, dkk. 2016) pada proses pembelian buah naga dibeli di pasar, dan buah naga terdapat pada keranjang dan ditumpuk, serta kondisi kulit buah naga yang kurang baik.

Pada pembuatan bubuk kulit buah naga juga dapat berpengaruh pada aktivitas antioksidan sejalan dengan penelitian (Yamin, dkk. 2017) Suhu dan waktu yang digunakan dalam proses pengeringan memiliki pengaruh sangat nyata terhadap aktivitas antioksidan. Dalam kondisi ini dapat disebabkan karena selama proses pengeringan menyebabkan zat aktif yang terkandung didalam suatu bahan pangan menjadi rusak.

\section{Analisa Uji Umur Simpan}

Analisis uji umur simpan pada produk puding kulit buah naga dilakukan dengan metode direct method dilakukan dengan pengecekan secara berkala.

Daya simpan diketahui produk puding kulit buah naga hanya bertahan di suhu ruang selama 2 hari, dan pada hari ke 3 dan 4 sudah tidak layak konsumsi dikarenakan sudah terdapat bintik putih dan mengeluarkan air yang cukup banyak pada setiap produk. Puding dalam suhu pendinginan $\left(40^{\circ} \mathrm{C}\right)$ atau dibawahnya hanya dapat bertahan selama 1-2 hari. Menurut (Asiah, 2018) Faktor yang mempengaruhi umur simpan yaitu (1) Bahan baku, bahan baku pembuatan produk juga harus terjaga kualitasnya; (2) bahan pendukung, bahan pengemas menjadi dapat mempengaruhi umur simpan, karena memberikan perlindungan yang baik pada produk; (3) Pengolahan, sangat berpengaruh pada penentu umur simpan; (4) distribustor dan (5) retailer.

Pada produk pudding kulit buah naga ini mengandung banyak air yang menyebabkan salah satu faktor cepatnya mengalami kerusakan dan mempercepat pertumbuhan mikroba, sejalan dengan (Asiah, 2018) faktor yang dapat menurunkan kualitas dan mempercepat umur simpan adalah peningkatan atau pengurangan kadar air, peningkatan kadar air akan menyebabkan penyusutan dan menuruan kualitas bahan sensori dan terjadi pertumbuhan mikroba. Produk pudding kulit buah naga menunjukan bintik putih pada permukaan pudding yang kemungkinan disebabkan karena adanya mikroorganisme yang tumbuh pada puding. Menurut (Albiner, 2002) puding salah satu makanan yang mudah terkontaminasi mikroorganisme seperti Streptococcus pyogenes. Menurut (Badan Standardisasi 
Tabel 13. Hasil Uji Umur Simpan

\begin{tabular}{|c|c|c|c|c|}
\hline Sampel & Hari 1 & Hari 2 & Hari 3 & Hari 4 \\
\hline $\begin{array}{l}\text { F1 ( } 6 \% \text { bubuk } \\
\text { kulit buah } \\
\text { naga) }\end{array}$ & $\begin{array}{l}\text { - Aroma: susu } \\
\text { - Rasa : manis } \\
\text { - Warna : cream } \\
\text { - Tekstur : kenyal }\end{array}$ & $\begin{array}{l}\text { - Aroma : susu } \\
\text { - Rasa: manis } \\
\text { - Warna : cream } \\
\text { - Tekstur : kenyal }\end{array}$ & $\begin{array}{l}\text { - Aroma: susu } \\
\text { - Warna : cream } \\
\text { - Tekstur : kenyal } \\
\text { - Rasa : manis } \\
\text { - Kondisi : } \\
\text { mengeluarkan } \\
\text { banyak air }\end{array}$ & $\begin{array}{l}\text { - Aroma: susu } \\
\text { - Warna : cream } \\
\text { - Tekstur : kenyal } \\
\text { - Rasa : sedikit manis } \\
\text { - Kondisi : } \\
\text { mengeluarkan } \\
\text { banyak air dan } \\
\text { permukaan terdapat } \\
\text { bintik putih dan } \\
\text { cream }\end{array}$ \\
\hline $\begin{array}{l}\text { F2 (13\% bubuk } \\
\text { kulit buah } \\
\text { naga) }\end{array}$ & $\begin{array}{l}\text { - Aroma : susu } \\
\text { - Rasa : Manis } \\
\text { - Warna : Cream } \\
\text { - Tekstur :K enyal }\end{array}$ & $\begin{array}{l}\text { - Aroma: susu } \\
\text { - Rasa : manis } \\
\text { - Warna : cream } \\
\text { - Tekstur : kenyal }\end{array}$ & $\begin{array}{l}\text { - Aroma: susu } \\
\text { - Warna : cream } \\
\text { - Tekstur : kenyal } \\
\text { - Rasa : sedikit } \\
\text { manis } \\
\text { - Kondisi : } \\
\text { mengeluarkan } \\
\text { banyak air dan } \\
\text { di permukaan } \\
\text { terdapat bintik } \\
\text { putih } \\
\end{array}$ & $\begin{array}{l}\text { - Aroma: susu } \\
\text { - Warna : cream } \\
\text { - Tekstur : kenyal } \\
\text { - Rasa : tidak manis } \\
\text { - Kondisi : } \\
\text { mengeluarkan } \\
\text { banyak air dan } \\
\text { dipermukaan } \\
\text { terdapat bintik putih } \\
\text { dan cream di } \\
\text { pinggir wadah } \\
\end{array}$ \\
\hline $\begin{array}{l}\mathrm{F} 1(30 \% \text { bubur } \\
\text { kulit buah } \\
\text { naga) }\end{array}$ & $\begin{array}{l}\text { - Aroma : susu } \\
\text { dan kulit buah } \\
\text { - Rasa : Manis } \\
\text { - Warna : pink } \\
\text { muda } \\
\text { - Tekstur : Kenyal }\end{array}$ & $\begin{array}{l}\text { - Aroma : susu } \\
\text { dan kulit buah } \\
\text { - Rasa : Manis } \\
\text { - Warna : pink } \\
\text { muda } \\
\text { - Tekstur : } \\
\text { Kenyal }\end{array}$ & $\begin{array}{l}\text { - Aroma : susu } \\
\text { dan kulit buah } \\
\text { - Warna:pink } \\
\text { muda } \\
\text { - Tekstur : Kenyal } \\
\text { - Rasa : sedikit } \\
\text { manis } \\
\text { - Kondisi : } \\
\text { Mengeluarkan } \\
\text { banyak air dan } \\
\text { dipermukaan } \\
\text { terdapat bintik } \\
\text { putih }\end{array}$ & $\begin{array}{l}\text { - Aroma : susu dan } \\
\text { kulit buah } \\
\text { - Warna : pink muda } \\
\text { - Tekstur : Kenyal } \\
\text { - Rasa : tidak manis } \\
\text { - Kondisi : } \\
\text { Mengeluarkan } \\
\text { banyak air dan } \\
\text { dipermukaan } \\
\text { terdapat bintik putih } \\
\text { dan kuning }\end{array}$ \\
\hline $\begin{array}{l}\text { F2 ( } 40 \% \text { bubur } \\
\text { kulit buah } \\
\text { naga) }\end{array}$ & $\begin{array}{l}\text { - Aroma : susu dan } \\
\text { kulit buah } \\
\text { - Rasa : Manis } \\
\text { - Warna : pink } \\
\text { pekat } \\
\text { - Tekstur : Kenyal }\end{array}$ & $\begin{array}{l}\text { - Aroma : susu } \\
\text { dan kulit buah } \\
\text { - Rasa : Manis } \\
\text { - Warna : pink } \\
\text { pekat } \\
\text { - Tekstur : Kenyal }\end{array}$ & $\begin{array}{l}\text { - Aroma : susu dan } \\
\text { kulit buah } \\
\text { - Warna : pink } \\
\text { pekat } \\
\text { - Tekstur : Kenyal } \\
\text { - Rasa : tidak } \\
\text { manis } \\
\text { - Kondisi : } \\
\text { Mengeluarkan } \\
\text { banyak air dan } \\
\text { dipermukaan } \\
\text { terdapat bintik } \\
\text { putih } \\
\end{array}$ & $\begin{array}{l}\text { - Aroma : susu dan } \\
\text { kulit buah } \\
\text { - Warna : pink pekat } \\
\text { - Tekstur : Kenyal } \\
\text { - Rasa : tidak manis } \\
\text { - Kondisi : } \\
\text { Mengeluarkan } \\
\text { banyak air dan } \\
\text { dipermukaan } \\
\text { terdapat bintik putih } \\
\text { dan kuning, serta } \\
\text { terdapat gumpalan } \\
\text { putih. } \\
\end{array}$ \\
\hline
\end{tabular}

Nasional,2009) mikroorganisme yang sering ditemukan di dalam pudding seperti Staphylococcus aureus, bakteri ini tumbuh dengan baik pada pangan yang mengandung protein tinggi, gula tinggi dan garam. 


\section{KESIMPULAN}

Produk puding kulit buah naga yang dihasilkan wrananya pink, beraroma kulit buah naga, rasa mani dan tekstur lembut serta mengandung antioksidan. Produk puding ini yang mengandung antioksidan yang paling baik adalah sebesar 159.49 ppm. Berdasarkan nilai ppm pada hasil didapat semakin rendah nilai ppm nya maka aktifitas antioksidannya semakin tinggi sehingga produk ini baik dikonsumsi oleh masyarakat untuk dapat menjaga imunitas dalam tubuh agar tetap terjaga sehingga terhindar dari berbagi penyakit. Dan pada hasil umur simpan rerata rata-rata puding di suhu ruang kuat dalam dua hari.

\section{UCAPAN TERIMAKASIH}

Penulis mengucapkan terima kasih kepada teman-teman dan masayarakat atas bantuannya yang telah bersedia menjadi panelis. Terima kasih juga kepada semua pihak yang telah memberikan dukungan serta membantu yang tidak bisa saya sebutkan satu persatu dalam penelitian ini.

\section{DAFTAR PUSTAKA}

Albiner Siagian. 2002. Mikroba Patogen Pada Makanan Dan Sumber Pencemarannya. www.USU digital library.com (Diakses Senin, 4 Januari 2021 pukul 19.00 WIB)

Arini, W. 2015. Kadar Anti Oksidan dan Uji Organoleptik Puding Kulit Buah Manggis Dengan Penambahan Buah Kurma Sebagai Perasa Manis Alami. Naskah Publikasi. Fakultas Keguruan dan IImu Pendidikan Biologi, Universitas Muhammadiyah Surakarta.

Arnanda Q A, Nurwarda R F.2019. Review Article: Penggunaan Radiofarmaka Teknesium-99M Dari Senyawa Glutation Dan Senyawa Flavonoid Sebagai Deteksi Dni Radikal Bebas Pemicu Kanker. Farmaka. 17 (2):236-242

Arysantini R D, Sulistiyani, Rohmawati. 2019. Indeks Glikemik, kandungan gizi, dan daya terima puding ubi jalar putih
(Ipomoe batatas) dengan penambahan buah naga merah (Hylocereus polyrhizus). Amerta Nutrition. 107-113

Aryantini D. 2021. Aktivitas Antioksidan Dan

Kandungan Tanin Total Ekstrak Etanol Daun Kupu-Kupu (Bauhinia purpurea L.). Jurnal Farmagazine. 8(1):54-60

Asiah N, Cempaka L, David W. 2018. Panduan Praktis Pendugaan Umur Simpan Produk Pangan. Jakarta: Universitas Bakrie

Ayu, T. 2013. Pengaruh Penggunaan Bahan Pembentuk Gel Terhadap Kualitas Permen Jeli Kulit Buah Naga Merah (Hylocereus Polyrhizus). Skripsi. Padang: Universitas Negeri Padang Badan Standarisasi Nasional. (2009). Batas Maksimum Cemaran Mikroba dalam Pangan. SNI-2981. Jakarta: Badan Standar Nasional

Budilaksono, W. Wahdaningsih S, Fahrurroji A. Uji Aktivitas Antioksidan Fraksi NHeksana Kulit Buah Naga Merah (Hylocereus lemairei Britton dan Rose) Menggunakan Metode Dpph (1,1-Difenil2-Pikrilhidrazil). 1(1). 1-11

Institute for Health Metrics and Evaluation (IHME). Findings from the Global Burden of Disease Study 2017. Seattle, WA: IHME, 2018

Intan. R. 2013 Pengaruh Konsentrasi Agaragar Karagenan Terhadap Karakteristik Fisik Kimia Dan Sensori Selai Lembaran Pisang (Musa paradisiaca L.) Var. Raja Bulu Jam slice. Jurnal. Universitas Sebelas Maret. Surakarta

Kristanto, D. (2008). Buah Naga Pembudidayaan di Pot dan di Kebun. Penebar Swadaya.

Mahargyani W. 2018. Identifikasi Senyawa Dan Uji Aktivitas Antioksidan Ekstrak Etanol Kulit Buah Naga Merah (Hylocereus Polyrhizus). PINLITAMAS 1. 1(1): 614-621 
Maulina L, Sugihartini N. 2015. Formulasi Gel Ekstrak Etanol Kulit Buah Manggis (Garcinia mangostana L.) Dengan Variasi Gelling Agent Sebagai Sediaan Luka Bakar. 5(1). 43-52

Noor MI, Yufita E, Zulfalina. 2016. Identifikasi Kndungan Ekstrak Kulit Buah Naga Merah Menggunakan Fourier Transform Infrared (FTIR) dan Fitokimia. Journal of Aceh Physics Society (JAcPS). 5 (1): 1416.

Nurliyana, R., Zahir, I. S., Suleiman, K. M., Aisyah, M.R., dan Rahim, K. K., 2010, Antioxidant study of pulps and peels of dragon fruits: a comparative study, International Food Research Journal, 17 :367-365

Raini M, Isnawati A. 2011. Kajian: Khasiat Dan Keamanan Stevia Sebagai Pemanis Pengganti Gula. Media Litbang Kesehatan. 21(4): 145-156

Riset Kesehatan Dasar (Riskesdas) (2018). Laporan Nasional RISKESDAS 2018. Badan Penelitian dan Pengembangan Kesehatan Kementerian RI tahun 2018

Riset Kesehatan Dasar (Riskesdas) (2018). Laporan Provinsi Jawa Barat RISKESDAS 2018. Badan Penelitian dan Pengembangan Kesehatan Kementerian RI tahun 2018

Saneto, B. 2005. Karakterisasi kulit buah naga merah (Hylocereus polyrhizus.). Jurnal Agarika. Vol 2:143-149

Siwi AN, (2018) Pengaruh Pewarna Kulit Buah Naga Merah Terhadap Potensi Antioksidan, Warna Dan Sensoris Permen Jelly Jagung (Zea Mays. L). Thesis, Surakarta: STIKES PKU Muhammadiyah Surakarta.201

Sulistianingsih $Y$, Johan VS, Herawati N. 2017. Pemanfaatan Kulit Buah Naga
Merah Dalam Pembuatan Permen Jelly Buah Papeda. Jom FAPERTA. 4(2): 1-13 Suparmajid A H, Mulyani S S, Ratman. 2016. Pengaruh Lama Penyimpanan Rimpang Kunyit (Curcuma domestica Vahl) Terhadap Daya Hambat Antioksidan. 5(1). 1-7.

Tezar. Aminah. Bain Ali, 2008. Optimasi Pemanfaatan Stevia sebagai Pemanis Alami pada Sari buah Belimbing Manis. Agriplus, 18(3)

Utami W, Mardawati E, Putri SH. 2020. Pengujian Aktivitas AntioksidaN Kulit Buah Naga Merah (Hylocereus polyrhizus) Sebagai Masker Gel Peel off. Jurnal Industri Pertanian. 2(1): 95-102.

Purwanto D, Bahri S, Ridhay A. UJI Aktivitas Antioksidan Ekstrak Buah Purnajiwa (Kopsia arborea Blume.) Dengan Berbagai Pelarut. KOVALEN. 3(1). 24-32 Wahyuni, R. (2011). Pemanfaatan Kulit Buah Naga Super Merah (Hylicereus costaricensis) sebagai Sumber Antioksidan dan Pewarna Alami pada Pembuatan Jelly. Jurnal Teknologi Pangan, 2(1), 68-85.

Winahyu D A, Purnama R C, Setiawati M Y.2019. Test Of Antioxidant Activities In Red Dragon Fruit Extract (Hylocereus Polyrhizus) Using Dpph Method. Jurnal Analis Farmasi. 4(2) 117-121

Winarsi, H. (2007). Antioksidan Alami dan Radikal Bebas. Kansius

Yamin Muhammad, Furtuna Dewi Ayu, Hamzah Faizah. 2017. Lama Pengeringan Terhadap Aktivitas Antioksidan Dan Mutu Teh Herbal Daun Ketepeng Cina (Cassia Alata L.). Jom Faperta.Vo.4. No. 2. 